\title{
Electricity consumption of drying and the effect of the dryer and temperature on the chemical quality of nettle leaves (Urtica dioica L.), birch leaves (Betula pendula, Betula pubescens) and roseroot (Rhodiola rosea L.)
}

Eveliina Isosaari ( $\nabla$ eveliina.isosaari@centria.fi )

Centria University of Applied Sciences

Jaana Väisänen

Centria University of Applied Sciences

Leena Favén

Centria University of Applied Sciences

Research Article

Keywords: drying temperature, electricity consumption, chemical quality, polyphenols, antioxidants

Posted Date: September 13th, 2021

DOI: https://doi.org/10.21203/rs.3.rs-892418/v1

License: (1) (i) This work is licensed under a Creative Commons Attribution 4.0 International License.

Read Full License 


\title{
Electricity consumption of drying and the effect of the dryer and temperature
} on the chemical quality of nettle leaves (Urtica dioica L.), birch leaves (Betula pendula, Betula pubescens) and roseroot (Rhodiola rosea L.)

\author{
Eveliina Isosaari, Jaana Väisänen \& Leena Favén
}

Corresponding author: Eveliina Isosaari: Centria University of Applied Sciences, (Chemistry and Bioeconomy Research Team), Kokkola, Finland. E-mail, eveliina.isosaari@centria.fi. ORCID: 00000002-5644-2153

Jaana Väisänen (temporarily unaffiliated): Oulu, Finland.

Leena Favén: Centria University of Applied Sciences, (Chemistry and Bioeconomy Research Team), Kokkola, Finland. ORCID: 0000-0003-2585-556

\section{Acknowledgements}

Mr. Kari Perttula, Ms. Ritva Mäkelä and Mr. Jarkko Sulasalmi are recognized for conducting the laboratory analyses and Mr. Antti Takalo and Mr. Vinh Nguyen for carrying out the drying experiments. Specials thanks are provided to Mr. Antti Takalo also for modifying and improving the convective dryer. Grateful thanks are offered to Osuuskunta Ärmätti for providing nettles and Kimmo Kentala and Unto Pulkkinen for providing roseroot for the drying experiments.

The study was supported by European Regional Development Fund through Interreg Nord Programme (MoreNPBiz-project). 


\section{Declarations}

\section{Funding}

The study was supported by European Regional Development Fund through Interreg Nord Programme (MoreNPBiz-project).

\section{Conflicts of interest/Competing interests}

The authors have no conflicts of interest to declare that are relevant to the content of this article.

\section{Data availability}

All data analysed during this study are included in this published article and its supplementary information files.

\section{Code availability}

Not applicable.

\section{Authors' contributions}

The idea of the research arrived from Jaana Väisänen and Leena Favén. The research plan, data collection and interpretation was performed by Eveliina Isosaari. The first draft of the manuscript was written by Eveliina Isosaari and all authors commented on previous versions of the manuscript. All authors read and approved the final manuscript. 


\begin{abstract}
Drying can constitute the majority of the energy costs and thus, manufacturing costs, in plant refining. The use of higher drying temperatures accelerates drying and reduces total electricity consumption. However, higher drying temperatures can also reduce the chemical quality of plants, as heat sensitive compounds can degrade or evaporate. The purpose of the study was to find the optimum drying temperature for nettle leaves (Urtica dioica L.), white and silver birch leaves (Betula pubescens, Betula pendula) and roseroot (Rhodiola rosea L.) in terms of electricity consumption and quality. Selected plants were dried with drying oven, convective dryer and vacuum dryer between 40 and $80{ }^{\circ} \mathrm{C}$. The quality was determined by measuring total polyphenol content, antioxidant capacity and active compounds of roseroot. The lowest total electricity consumption was obtained by drying oven, but the highest chemical quality was obtained by vacuum dryer. The optimum drying temperature varied between 65 and $80^{\circ} \mathrm{C}$.
\end{abstract}

Keywords: drying temperature; electricity consumption; chemical quality; polyphenols; antioxidants 


\section{Introduction}

The market of natural and organic products, including food, consumer packaged goods, personal care products, cosmetics and supplements, has increased over the years and it's expected to grow even more $[1,2]$. In the United States, the revenue of natural products grew from US\$ 51 billion to US\$ 64 billion from mid-2015 to mid-2019. In this time, approximately 3600 natural brands emerged in the markets [2].

Due to increasing market, competition and fraud products, it is important be able to stand out from the mass and offer high-quality of products [1-3]. Besides good quality ingredients, also processing should be conducted in a way that preserves quality. Drying, grinding and chopping can cause chemical compounds to degrade or evaporate. This can lead to changes in shape, structure and color, loss of aroma and nutrients and inactivation of bacteria and enzymes [4-6]. However, drying is needed for longer storage time, to prevent the growth and reproduction of micro-organisms, to minimize packaging size and to reduce transport weight $[5,6]$. By controlling and optimizing the drying conditions, the properties of the ingredients can be preserved to a greater extent and without considerable reduction in quality [6].

Polyphenols are secondary metabolites of plants produced to protect against the UV-radiation and pathogen aggression $[7,8]$. They also affect color, flavor, odor, astringency, bitterness and oxidative stability of plants and plant-based products [8]. In human diet, polyphenols are recognized as antiinflammatory, antiviral and antimicrobial $[7,9]$. Thus, polyphenols are responsible for several quality characteristics of plant-based products.

Several polyphenols also act as antioxidants, which are believed to play a protective role in our health. Antioxidants can prevent the oxidation of other compounds leading themselves being oxidized. In human cells, they can protect proteins, lipids and DNA from oxidation caused by free radicals such as nitrogen and oxygen radicals. In the worst case, free radicals can cause irreversible damage to cellular structures causing cancer or other chronic diseases [10].

Many plants also contain compounds of particular interest. In roseroot (Rhodiola rosea L.), these are salidroside, tyrosol, rosarin, rosavin, rosin and cinnamyl alcohol. Rosin, rosarin and rosavin are derivatives of cinnamyl alcohol and salidroside is a derivative of tyrosol. Rosarin, rosavin and rosin, known under the collective name of rosavins, are considered the most important compounds of roseroot as they are not found in any other species of the Rhodiola genus [11,12].

Drying can cover the most of the energy costs or even total costs of the processing chain [13]. According to Müller \& Heindl (2006) [13], drying accounts for 30 to $50 \%$ of the total costs of the 
production of medicinal plants, where low drying temperatures and long drying times are used. A contemplated selection of the dryer and temperature can reduce the energy consumption of drying. For example, freeze drying and vacuum drying consume more electricity than convective drying, but the quality of dried plants is often higher $[4,5,14]$. Microwave drying consumes less electricity than convective drying, but the dryer itself is rather expensive [14,15]. Solar drying consumes only energy from the sun, but the drying process is slow and the material is exposed to weather conditions and contaminants [5].

Expensive equipment investments in drying often lead to the use of cheaper conventional dryers such as drying oven or convective dryer $[4,5,15]$. Hybrid drying, a combination of two drying methods, could improve quality of drying, decrease electricity consumption or shorten the drying time [5]. For example, a microwave-vacuum dryer is considered having the advantages of both microwave dryer and vacuum dryer: low electricity consumption and good quality of plant-based products. Microwaveconvective dryer instead enables short drying time, as the penetration of microwaves facilitates the moisture movement from inside of the material to the surface, where hot airflow displaces it [16].

This study attempted to find the optimum drying temperature for nettle leaves (Urtica dioica L.), birch leaves (Betula pubescens, Betula pendula) and roseroot in terms of quality and energy consumption. The selected plants were dried with conventional drying oven, improved convective dryer and vacuum dryer using the temperatures of 40 to $80{ }^{\circ} \mathrm{C}$. The quality of the dried plants was assessed by determining total polyphenol content and antioxidant capacity. In addition, the compounds of roseroot, salidroside, tyrosol, cinnamyl alcohol and rosavins, were analyzed by high performance liquid chromatograph (HPLC).

\section{Materials and methods}

\section{Chemicals and reagents}

Methanol, Folin-Ciocalteu's phenol reagent, sodium carbonate, copper(II) chloride dihydrate, ammonium acetate, neocuproine, gallic acid (synthesis grade), ( \pm )-6-hydroxy-2,5,7,8tetramethylchromane-2-carboxylic acid (trolox), rosarin, rosavin, rosin, tyrosol and cinnamyl alcohol were purchased from Merck KGaA (Darmstadt, Germany). Salidroside was purchased from Extrasynthese (Genay, France). Acetonitrile and trifluoroacetic acid were purchased from VWR Chemicals (Radnor, PA, USA). Ethanol Etax A was purchased from Altia Oyj (Helsinki, Suomi).

\section{Samples}

Cultivated nettle was obtained from a farm in Kainuu, Finland. Birch leaves, including both white birch and silver birch leaves, were collected from freshly felled trees in Central Ostrobothnia, Finland. The 
nettle leaves and birch leaves were separated from the stalks and branches prior to drying. Cultivated roseroot was obtained from a farm in Central Ostrobothnia, Finland. The rhizomes and roots of roseroot were chopped into smaller pieces, washed out of the remaining soil and sliced with a vegetable cutter. The nettle leaves, birch leaves and roseroot slices were stored in a freezer at $-20^{\circ} \mathrm{C}$ until drying.

\section{Drying}

Plants were spread out in a thin layer to the drying level and dried at $40,50,55,60,65,70$ and $80^{\circ} \mathrm{C}$, except of convective dryer, where the highest possible drying temperature was $75{ }^{\circ} \mathrm{C}$. A duplicate drying was performed at each temperature point. The moisture content of the plants was assessed by weighing before and during the drying. After a certain mass loss, usually 63 to $78 \%$ depending on the starting moisture, the drying was stopped.

Typically, a moisture content of 8 to $12 \mathrm{~m}$-\% is suitable for dried plants. Higher moisture content reduces the shelf-life of plant-based products and enables the growth of micro-organisms [13]. Thus, the aim of the drying was to achieve a moisture content of $12 \mathrm{~m}$-\%, as significantly lower moisture content would cause unnecessary electricity consumption.

The electricity consumption of the dryers was measured by an electric kWh meter (Carlo Gavazzi EM340), which was installed between the electric supply and the dryer. The recording of the electricity consumption started after the dryer had reached the drying temperature, and it was recorded for one hour. Data was collected on the drying temperatures of 40,60 and $80^{\circ} \mathrm{C}\left(75^{\circ} \mathrm{C}\right.$ with convective dryer) covering the lowest, middle and highest temperature of the drying range. Total electricity consumption was calculated by multiplying the electricity consumption (kWh) by the drying time (h).

Dryers

Three small-scale dryers were used in the drying experiments: conventional drying oven, modified convective dryer and vacuum dryer. The conventional drying oven was a well-insulated laboratory scale Thermo Heraeus T6030 heating and drying oven. The vacuum dryer was also a laboratory scale dryer, Vacucell 55 Eco attached to a vacuum pump Vacubrand MD 4C NT.

A vacuum dryer is similar to a conventional drying oven, except drying occurs in a vacuum without ambient air. The absence of air, especially oxygen, reduces the amount of unwanted chemical reactions and improves the quality of dried plants. Vacuum also intensifies water evaporation, as air and water vapor expand, the material swells and its volume and surface area increase. This leads to better heat transfer between the material and the environment. However, the main disadvantage of the vacuum drying is the high energy consumption [16]. 
The convective dryer used in the experiments was a modified and improved version of a small-scale Orakas Hyötykasvikuivuri 5521. The thermostat and heat and blower unit of Orakas Hyötykasvikuivuri are located at the bottom of the dryer, making the temperature control challenging and causing heat to deviate unevenly in the dryer. To improve the heat distribution, the dryer was turned on its side to obtain horizontal airflow and the drying shelves were installed in a new position. A new thermostat (Omron E5C PID) was installed in the dryer, improving the accuracy of temperature control. In addition, an air recirculation channel was added to the dryer to recycle warm exhaust air back into the fresh air inlet. This modification improved the energy efficiency and reduced the electricity consumption of the dryer.

Convective drying is perhaps the most common and widely used method for drying fruits, vegetables and medicinal plants. In the drying process, water diffuses to the surface of the material by a moisture concentration gradient, from which hot airflow displaces it. However, the method has downsides: low energy efficiency and thermal conductivity [16-17]. Also, the water diffusion is slow, prolonging the drying and exposing the material more to the oxygen [17]. Convective drying can also cause hardening and shrinkage of the dried plants [16].

\section{Moisture content}

The dried plants were ground with IKA A11 analytical mill into fine powder. The samples were stored at $\mathrm{RT}$ in plastic jars. The moisture content was determined by drying $1.5 \mathrm{~g}$ of sample at $105 \pm 5{ }^{\circ} \mathrm{C}$ overnight (at least 15h) and calculating the mass loss. A duplicate moisture content was made from each sample.

\section{Extraction}

The dried and powdered plants were extracted ultrasonic-assisted. The extraction parameters (solvent, solid-solvent ratio, temperature and extraction rounds) were selected based on limited experiments. Each sample underwent a duplicate extraction and each extract a duplicate analysis to exclude the effect of natural variations and sampling (Fig. 1).

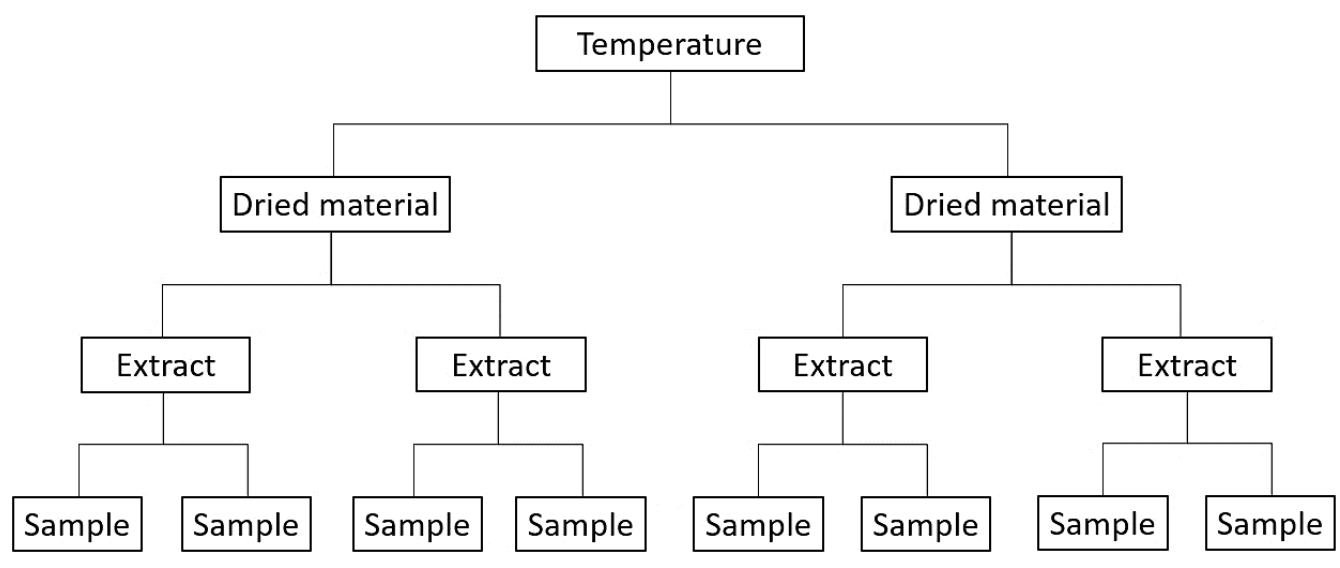


Fig. 1 The implementation of the drying trials and quality characterization.

One (1) gram of nettle leaf powder was mixed with $60 \mathrm{ml}$ of deionized water in a $100 \mathrm{ml}$ Erlenmeyer flask with a screw cap. The mixture was sonicated for 30 minutes at $30^{\circ} \mathrm{C}$. Then, the extract was mixed with $20 \mathrm{ml}$ of $94 \%(\mathrm{v} / \mathrm{v})$ ethanol and filtered through $1.20 \mu \mathrm{m}$ and $0.45 \mu \mathrm{m}$ PTFE filters to separate the extract from the solid residue.

One (1) gram of birch leaf powder was mixed with $40 \mathrm{ml}$ of 50\% ethanol in a $100 \mathrm{ml}$ Erlenmeyer flask with a screw cap. The mixture was sonicated for 30 minutes at $30^{\circ} \mathrm{C}$. Then, the extract was centrifuged for 10 minutes at $4000 \mathrm{rpm}$. Ten (10) milliliters of the supernatant was recovered and the solid residue transferred back to the Erlenmeyer flask. The residue was re-extracted with $40 \mathrm{ml}$ of $50 \%$ ethanol and centrifuged. Ten (10) milliliters of supernatant was recovered and combined with the first supernatant.

One (1) gram of roseroot powder was mixed with $20 \mathrm{ml}$ of $70 \%$ methanol in a $100 \mathrm{ml}$ capful Erlenmeyer flask with a screw cap. The mixture was sonicated for 30 minutes at $30{ }^{\circ} \mathrm{C}$. Then, the extract was centrifuged for 10 minutes $4000 \mathrm{rpm}$. Five (5) millilitres of the supernatant was recovered and the solid residue was transferred back to the Erlenmeyer flask. The residue was re-extracted with $20 \mathrm{ml}$ of $70 \%$ methanol, centrifuged and 5 millilitres of supernatant recovered. The extraction was repeated once more and all three supernatants were combined.

\section{Quality characterization}

Total polyphenol content

Total polyphenol content (TPC) was determined by Folin-Ciocalteu's assay using the procedure described by Mota et al. (2012) [18]. Half (0.5) $\mathrm{ml}$ of extract was mixed with $2.5 \mathrm{ml}$ of Folin-Ciocalteu's phenol reagent $(0.2 \mathrm{M})$ and $2.0 \mathrm{ml}$ of sodium carbonate solution $(75 \mathrm{~g} / \mathrm{l})$. The mixture was heated in a water bath at $50{ }^{\circ} \mathrm{C}$ for 5 minutes and cooled to RT. The absorbance was recorded by Shimadzu UV1800 spectrophotometer at $760 \mathrm{~nm}$ against reagent blank. Gallic acid $(0.01-0.10 \mathrm{mg} / \mathrm{ml})$ was used as a standard and the results are expressed as gallic acid equivalents per dry weight (mg GAE/g dw).

\section{Antioxidant capacity by CUPRAC}

Antioxidant capacity (AC) was determined by CUPRAC (cupric ion reducing antioxidant capacity) assay using the procedure described by Özyürek et al. (2011) [19]. One (1) ml of copper chloride (0.01 M), 1 $\mathrm{ml}$ of ammonium acetate $(1.0 \mathrm{M}), 1 \mathrm{ml}$ of neocuproine $(0.0075 \mathrm{M})$ and $1 \mathrm{ml}$ of water was mixed with $0.1 \mathrm{ml}$ of extract. The mixture was left to react to dark, at RT, for 30 minutes. The absorbance was recorded by Shimadzu UV-1800 spectrophotometer at $450 \mathrm{~nm}$ against reagent blank. Trolox (0.01 - 
$0.25 \mathrm{mM}$ ) was used as a standard and the results are expressed as Trolox equivalents per dry weight (mmol TE/g dw).

HPLC analysis of active compounds in roseroot

The analysis of salidroside, tyrosol, cinnamyl alcohol and rosavins was performed with HPLC, Shimadzu LC-20A Prominence, equipped with diode array detector (DAD). The assay is based on the procedures described by Marchev et al. (2017) [20] and Peschel et al. (2016) [21]. The extracts were filtered through $0.45 \mu \mathrm{m}$ PTFE filters and transferred into vials. The column was Waters XBridge C18 (3.5 $\mu \mathrm{m}$, $4.6 \times 150 \mathrm{~mm}$ ) and mobile phases were A: $0.1 \%$ TFA in acetonitrile and B: deionized water. The gradient conditions were as follows: $0-10 \mathrm{~min} 90 \% \mathrm{~B} ; 10-25 \mathrm{~min}$ from $90 \%$ to $80 \% \mathrm{~B} ; 25-35 \mathrm{~min}$ from $80 \%$ to $55 \% \mathrm{~B} ; 35-39 \mathrm{~min} 10 \% \mathrm{~B}$ and $39 \mathrm{~min} 90 \% \mathrm{~B}$ with $4.5 \mathrm{~min}$ post-run time. Other parameters were $1 \mathrm{ml} / \mathrm{min}$ flow rate, $30{ }^{\circ} \mathrm{C}$ column temperature and $10 \mu \mathrm{L}$ sample injection. The detection of salidroside and tyrosol occurred at $225 \mathrm{~nm}$ and the detection of cinnamyl alcohol and rosavins at 254 $\mathrm{nm}$. Corresponding standards $(0.100-0.150 \mathrm{mg} / \mathrm{ml})$ were used in the quantification and the results are expressed per dry weight $(\mathrm{mg} / \mathrm{kg} \mathrm{dw})$.

\section{Results and discussion}

Electricity consumption

The electricity consumption of the convective dryer, excluding the energy needed for heating, was $0.23,0.53$ and $0.98 \mathrm{kWh}$ per hour when the drying occurred at 40,60 and $75{ }^{\circ} \mathrm{C}$, respectively. The electricity consumption of the drying oven was $0.02,0.04$ and $0.08 \mathrm{kWh}$ per hour and the vacuum dryer was $0.33,0.33$ and $0.37 \mathrm{kWh}$ per hour when the drying occurred at 40,60 and $80^{\circ} \mathrm{C}$, respectively (Suppl. 1, Tab. 1). Thus, the lowest electricity consumption per hour was obtained with the drying oven, followed by the vacuum dryer and the convective dryer. With the vacuum dryer, higher drying temperatures did not increase the electricity consumption per hour as the cabinet is extremely well insulated.

The drying time was the shortest with the convective dryer followed by the vacuum dryer and the drying oven (Suppl. 1, Tab. 1). To obtain the total electricity consumption, the electricity consumption (kWh) per hour was multiplied with the spent drying hours (h). Even with the longest drying time, the drying oven clearly had the lowest total electricity consumption at each temperature. At 40 and $60^{\circ} \mathrm{C}$, the vacuum dryer typically had the highest total electricity consumption. At $80^{\circ} \mathrm{C}$, the drying time was short regardless of the dryer, resulting in the convective dryer having the highest total electricity consumption (Fig. 2). 


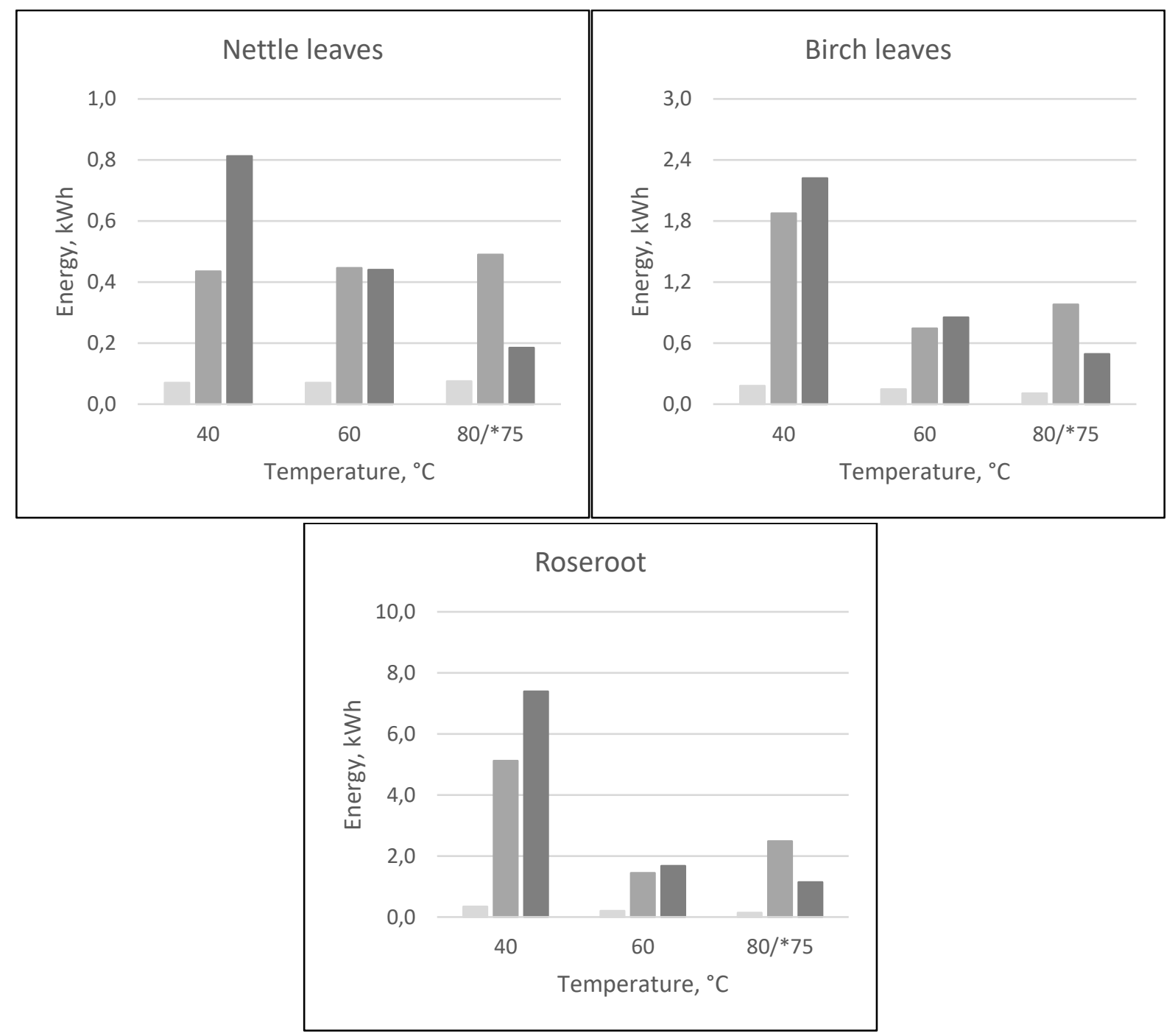

Fig. 2 Total electricity consumption of the dryers in the drying of nettle leaves, birch leaves and roseroot, where $\bullet$ is the drying oven, $\bullet$ the convective dryer and $\bullet$ the vacuum dryer.

${ }^{*}$ The convective dryer could not reach $80^{\circ} \mathrm{C}$, so the highest drying temperature was $75^{\circ} \mathrm{C}$.

The drying of nettle leaves occurred fast and therefore, total electricity consumption remained reasonable. With the drying oven and the convective dryer, temperatures between 40 and $80^{\circ} \mathrm{C}$ did not significantly affect total electricity consumption. However, the vacuum dryer achieved 46 and $77 \%$ lower total electricity consumption when the nettle leaves were dried at 60 and $80^{\circ} \mathrm{C}$ instead of 40 ${ }^{\circ} \mathrm{C}$, respectively.

The drying of birch leaves took approximately two to three times longer than the drying of nettle leaves (Suppl. 1, Tab. 1). The drying temperature did not have notable effect on total electricity consumption of the drying oven. However, the total electricity consumption of the convective dryer was 61 and $48 \%$ lower when dried at 60 and $75{ }^{\circ} \mathrm{C}$ instead of $40{ }^{\circ} \mathrm{C}$, respectively. Total electricity consumption of the vacuum dryer was 62 and $78 \%$ lower when dried at 60 and $80^{\circ} \mathrm{C}$ instead of $40^{\circ} \mathrm{C}$, respectively. 
Roseroot was dried in few millimeters' thick slices, slowing the transfer of water to the surface, significantly extending the drying time compared with nettle leaves and birch leaves [16]. At $40^{\circ} \mathrm{C}$, the drying took considerably more than 12 hours, so the drying was allowed to continue overnight. This resulted in all three dryers having the same drying time at $40^{\circ} \mathrm{C}$, causing a really high total electricity consumption for the convective dryer and the vacuum dryer. Total electricity consumption of the convective dryer was up to $256 \%$ higher and vacuum dryer up to $340 \%$ higher when dried at $40{ }^{\circ} \mathrm{C}$ instead of $60^{\circ} \mathrm{C}$, respectively. Thus, total electricity consumption could be considerably reduced by increasing the drying temperature from $40^{\circ} \mathrm{C}$ to 60 or $80^{\circ} \mathrm{C}$.

Depending on the temperature and the dried material, total electricity consumption of the drying oven was 5 to 18 times lower than that of the convective dryer and 2 to 22 times lower than that of the vacuum dryer. Differences in total electricity consumption of the dryers increased as the drying time lengthened. The greatest differences between the dryers were observed when the roseroot slices were dried at $40^{\circ} \mathrm{C}$.

\section{Moisture content}

The moisture content of dried nettle leaves varied between $4.52-21.68 \mathrm{~m}-\%, 3.08-27.33 \mathrm{~m}-\%$ and $3.66-22.27 \mathrm{~m}-\%$ when dried with the drying oven, convective dryer and vacuum dryer, respectively. The moisture content of dried birch leaves varied between $4.23-11.16 \mathrm{~m}-\%, 2.51-10.19 \mathrm{~m}-\%$ and $3.24-7.64 \mathrm{~m}-\%$ and the moisture content of roseroot between $4.70-15.02 \mathrm{~m}-\%, 4.61-12.30 \mathrm{~m}-\%$ and 2.05 - $16.40 \mathrm{~m}-\%$ when dried with the drying oven, convective dryer and vacuum dryer, respectively (Suppl. 2, Tab. 1.). The moisture content of nettle leaves was relatively high in part of the samples. Therefore, the dried samples were extracted and analyzed as fast as possible to avoid the growth and effect of micro-organisms on the results.

\section{Chemical quality}

TPC correlates strongly with AC. TPC of dried nettle leaves varied from 4.19 to $6.13 \mathrm{mg} \mathrm{GAE} / \mathrm{g} \mathrm{dw}$ with the drying oven, from 4.87 to $6.67 \mathrm{mg} \mathrm{GAE} / \mathrm{g}$ dw with the convective dryer and from 9.91 to $17.84 \mathrm{mg}$ $\mathrm{GAE} / \mathrm{g} \mathrm{dw}$ with the vacuum dryer. AC varied from 0.031 to $0.051 \mathrm{mmol} \mathrm{TE} / \mathrm{g} \mathrm{dw}$ with the drying oven, from 0.038 to $0.056 \mathrm{mmol} \mathrm{TE} / \mathrm{g} \mathrm{dw}$ with the convective dryer and from 0.129 to $0.195 \mathrm{mmol} \mathrm{TE} / \mathrm{g} \mathrm{dw}$ with the vacuum dryer (Suppl. 3, Tab. 1). Thus, significantly higher TPC and AC were achieved with the vacuum dryer. The difference in TPC and AC between the convective dryer and the drying oven is small, but slightly higher contents were measured from nettle leaves dried with the convective dryer (Fig. 3). 


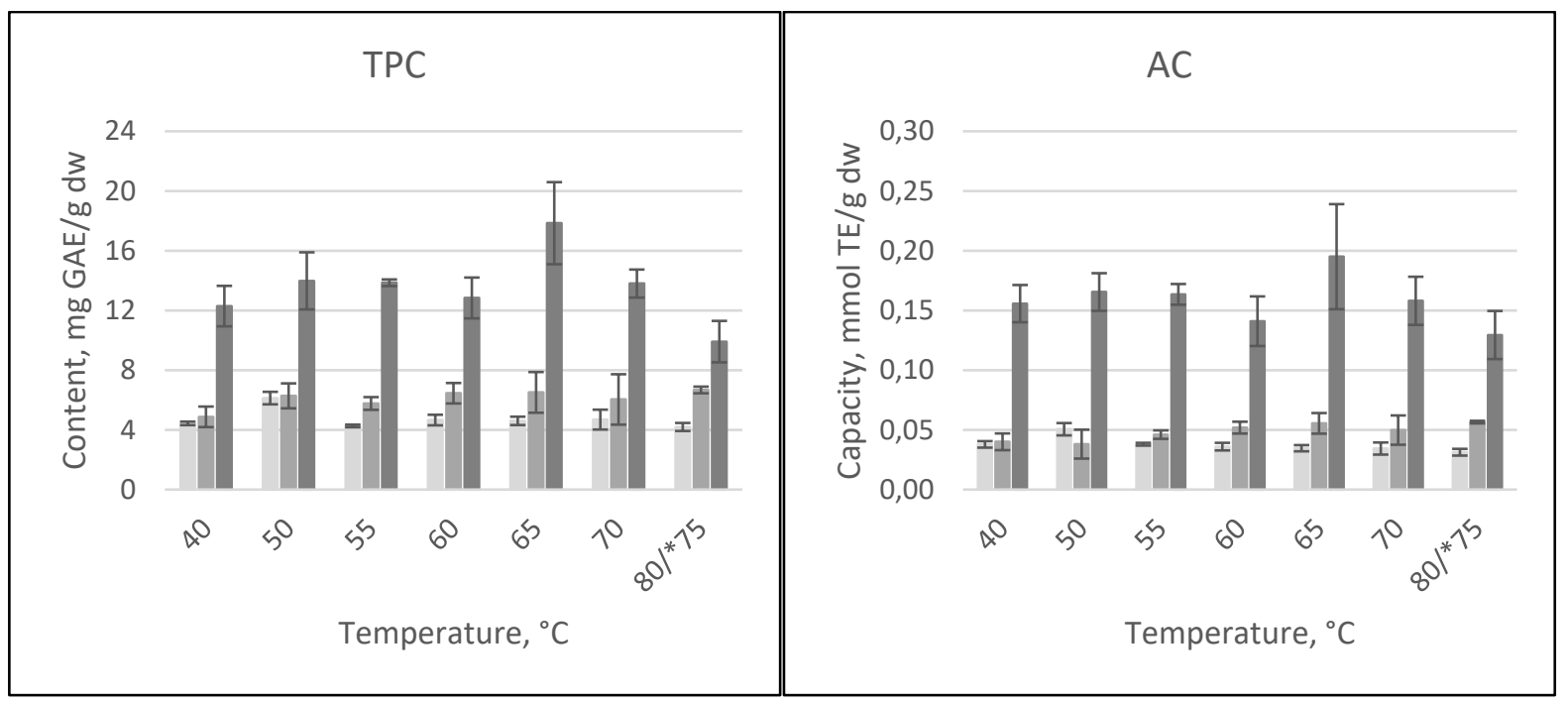

Fig. 3 Total polyphenol content (TPC) and antioxidant capacity (AC) of dried nettle leaves, where $\bullet$ is the drying oven, $\bullet$ the convective dryer and $\bullet$ the vacuum dryer.

${ }^{*}$ The convective dryer could not reach $80^{\circ} \mathrm{C}$, so the highest drying temperature was $75^{\circ} \mathrm{C}$.

Based on TPC and AC, the optimum drying temperature for nettle leaves appears to be $65{ }^{\circ} \mathrm{C}$ when dried with the vacuum dryer, 65 to $75{ }^{\circ} \mathrm{C}$ when dried with the convective dryer and $50{ }^{\circ} \mathrm{C}$ when dried with the drying oven. Thus, the highest TPC and AC are achieved at the drying temperatures of $50-75$ ${ }^{\circ} \mathrm{C}$ (Fig. 3).

Shonte et al. (2020) [4] found that compared with fresh and freeze-dried nettles, oven-dried nettles had the lowest $\beta$-carotene, vitamin $A$ and ascorbic acid content but the highest total phenol content and antioxidant activity. The loss of $\beta$-carotene, vitamin $A$ and ascorbic acid in the oven drying was suspected to be due to higher drying temperature $\left(70^{\circ} \mathrm{C}\right)$, which could cause the degradation or oxidation of the compounds. Also, Multari et al. (2018) [22] discovered in the drying of quinoa seeds and Delgado-Nieblas et al. (2015) [23] in the drying of naranjita pomace, that higher TPC was obtained when higher drying temperatures were used.

The increase of TPC at high drying temperatures is most likely caused by the positive effect of temperature on extraction. High drying temperature improves the release of polyphenols from the cellular structures of plants, raising their solubility in the extraction phase $[4,22]$. In addition, the breakage of bonds between polyphenols and sugars at high drying temperatures leads to the formation of aglycones that react better with Folin-Ciocalteu's reagent in the polyphenol assay $[4,24]$.

The effect of high drying temperatures on extraction efficiency is likely to explain the increase in AC as well. Antioxidants may also form in chemical reactions during drying or may be preserved to a greater extent due to the inactivation of oxidative enzymes [4]. 
TPC of dried birch leaves varied from 41.78 to $46.22 \mathrm{mg} \mathrm{GAE} / \mathrm{g} \mathrm{dw}$ with the drying oven, from 45.33 to $52.63 \mathrm{mg} \mathrm{GAE} / \mathrm{g} \mathrm{dw}$ with the convective dryer and from 57.62 to $65.31 \mathrm{mg} \mathrm{GAE} / \mathrm{g} \mathrm{dw}$ with the vacuum dryer. AC of birch leaves varied from 0.420 to $0.535 \mathrm{mmol} \mathrm{TE} / \mathrm{g} \mathrm{dw}$ with the drying oven, from 0.458 to $0.575 \mathrm{mmol} \mathrm{TE} / \mathrm{g} \mathrm{dw}$ with the convective dryer and from 0.608 to $0.689 \mathrm{mmol} \mathrm{TE} / \mathrm{g} \mathrm{dw}$ with the vacuum dryer (Suppl. 3, Tab. 2).

Also, with birch leaves, the highest TPC and AC were achieved when dried with the vacuum dryer. The drying temperature does not appear to have significant effect on TPC or AC of birch leaves. Only slightly higher contents were obtained at 65 to $80{ }^{\circ} \mathrm{C}$ when dried with the drying oven and the convective dryer. With the vacuum dryer, the quality remained similar throughout the temperature range (Fig. 4).

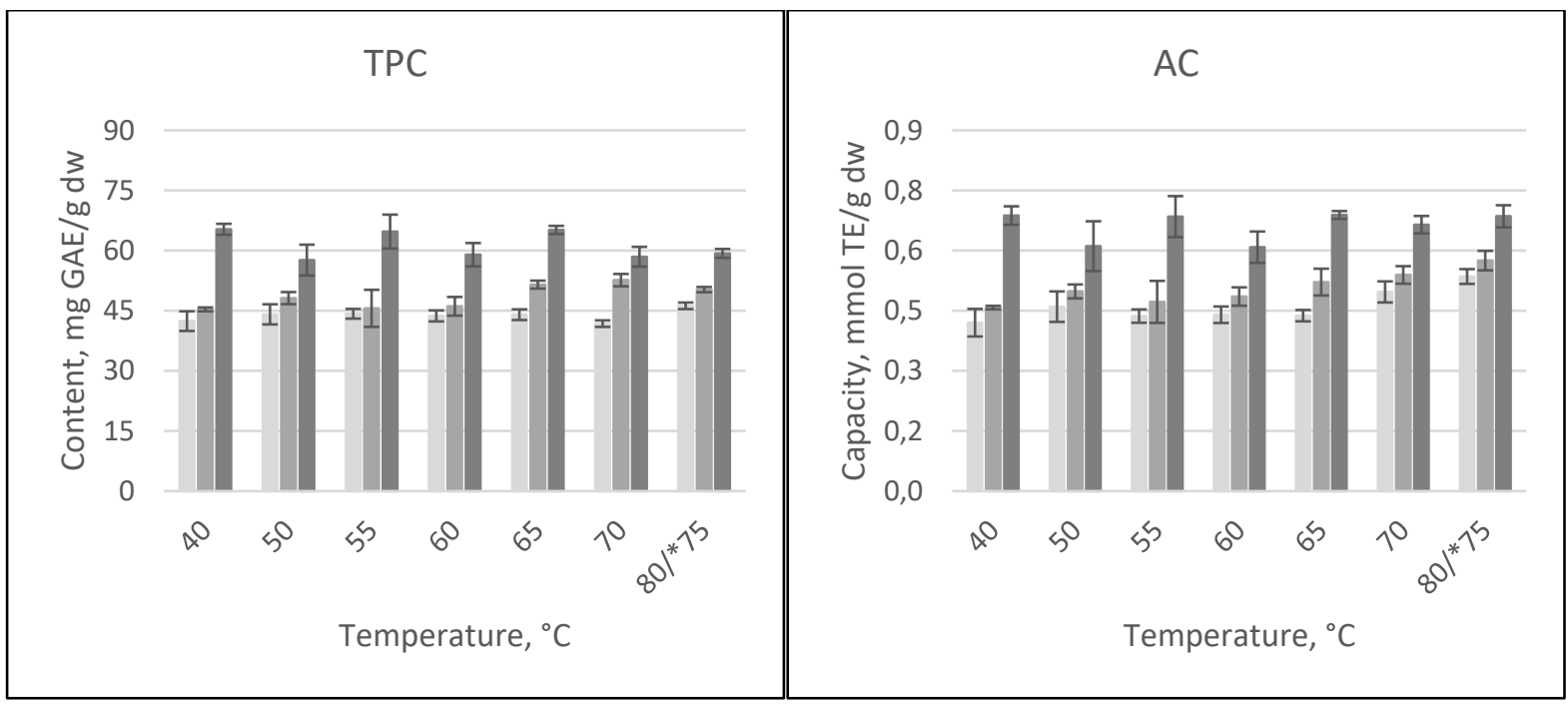

Fig. 4 Total polyphenol content (TPC) and antioxidant capacity (AC) of dried birch leaves, where is the drying oven, the convective dryer and $\bullet$ the vacuum dryer.

*The convective dryer could not reach $80^{\circ} \mathrm{C}$, so the highest drying temperature was $75^{\circ} \mathrm{C}$.

Keinänen \& Julkunen-Tiitto (1996) [25] studied the effect of various drying methods, including oven drying, on the content of individual polyphenols in birch leaves. They found the content of flavonoid glycosides to be higher in the oven drying at $80^{\circ} \mathrm{C}$ than at $40{ }^{\circ} \mathrm{C}$, but the content of other polyphenols was slightly lower. They suspected that the differences between temperatures could be explained by the different thermostability of the compounds and slower inactivation of enzymes at $40^{\circ} \mathrm{C}$.

TPC of dried roseroot slices varied from 92.24 to $180.78 \mathrm{mg}$ GAE/g dw with the drying oven, from 90.33 to $209.39 \mathrm{mg} \mathrm{GAE} / \mathrm{g} \mathrm{dw}$ with the convective dryer and from 105.19 to $195.81 \mathrm{mg} \mathrm{GAE} / \mathrm{g} \mathrm{dw}$ with the vacuum dryer. AC varied from 1.287 to $1.734 \mathrm{mmol} T E / g$ dw with the drying oven, from 1.242 to 
$1.970 \mathrm{mmol} \mathrm{TE} / \mathrm{g} \mathrm{dw}$ with the convective dryer and from 1.430 to $1.863 \mathrm{mmol} \mathrm{TE} / \mathrm{g} \mathrm{dw}$ with the vacuum dryer (Suppl. 3, Tab. 3).

Unlike in the results of nettle and birch leaves, the differences between the dryers are hardly significant with roseroot slices. Only slightly higher TPC and AC are obtained with the vacuum dryer when dried at $40-65{ }^{\circ} \mathrm{C}$ and with the convective dryer when dried at and above $70{ }^{\circ} \mathrm{C}$. This may indicate that the polyphenols and antioxidants of roseroot do not oxidize sensitively in the presence of air, and therefore the vacuum dryer does not distinguish itself from other dryers. The highest TPC and $\mathrm{AC}$ were obtained when the drying temperature was $70-80^{\circ} \mathrm{C}$ (Fig. 5).

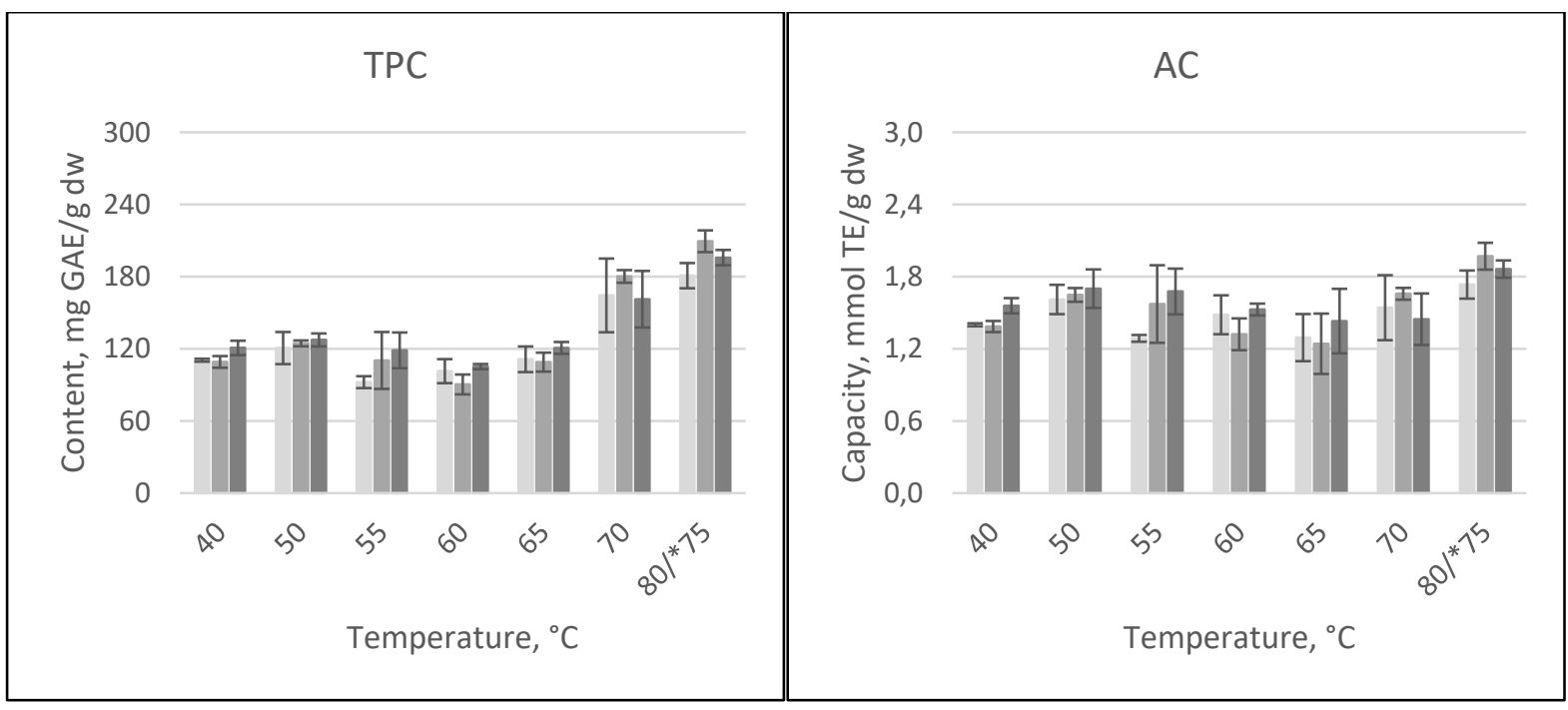

Fig. 5 Total polyphenol content (TPC) and antioxidant capacity (AC) of dried roseroot rhizomes and root, where $\bullet$ is the drying oven, $\bullet$ the convective dryer and $\bullet$ the vacuum dryer.

*The convective dryer could not reach $80^{\circ} \mathrm{C}$, so the highest drying temperature was $75^{\circ} \mathrm{C}$.

The ratio of rosavins (rosarin, rosavin and rosin) to salidroside is one way to demonstrate the quality of roseroot, as rosavins are the most important compounds of the plant. The highest rosavins to salidroside ratios $(1.77-2.05)$ were typically obtained at drying temperatures between 60 and $65^{\circ} \mathrm{C}$, and the lowest at 50,55 and $70^{\circ} \mathrm{C}$ (Fig. 6). This may be due to an increase in the content of rosavins or a decrease in the content of salidroside at $60-65^{\circ} \mathrm{C}$. 


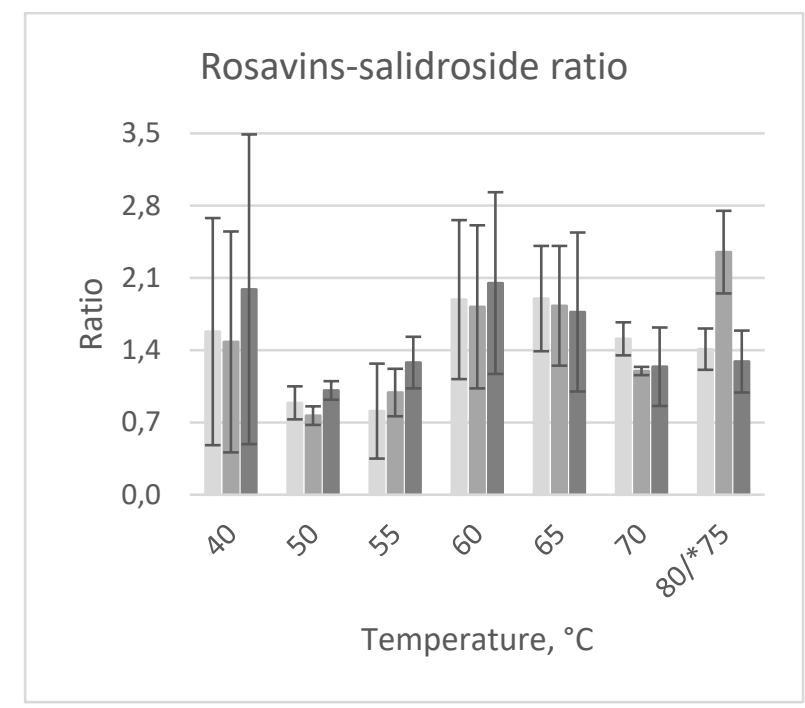

Fig. 6 Ratio of rosavins to salidroside, where $\bullet$ is the drying oven, $\bullet$ the convective dryer and - the vacuum dryer.

*The convective dryer could not reach $80^{\circ} \mathrm{C}$, so the highest drying temperature was $75^{\circ} \mathrm{C}$.

High standard deviation of salidroside, rosavin, rosin and tyrosol content does not allow reliable conclusions about the effect of drying temperature or dryers on the results (Fig. 7). Peschel et al. (2013) [26] found that the rhizomes of roseroot contain 2.5 to 3.5 times more rosavins than the roots. Thus, the ratio of rhizomes to roots in the samples affects the content of active compounds. This could explain the high standard deviation, as the ratio of roots to rhizomes of the samples was not determined.

The standard deviation of rosarin and cinnamyl alcohol is lower compared with other compounds, and a trend can be seen: the contents increase as the drying temperature rises. The highest rosarin and cinnamyl alcohol content were achieved when dried at $70{ }^{\circ} \mathrm{C}$ (Suppl. 3, Tab. 4). 


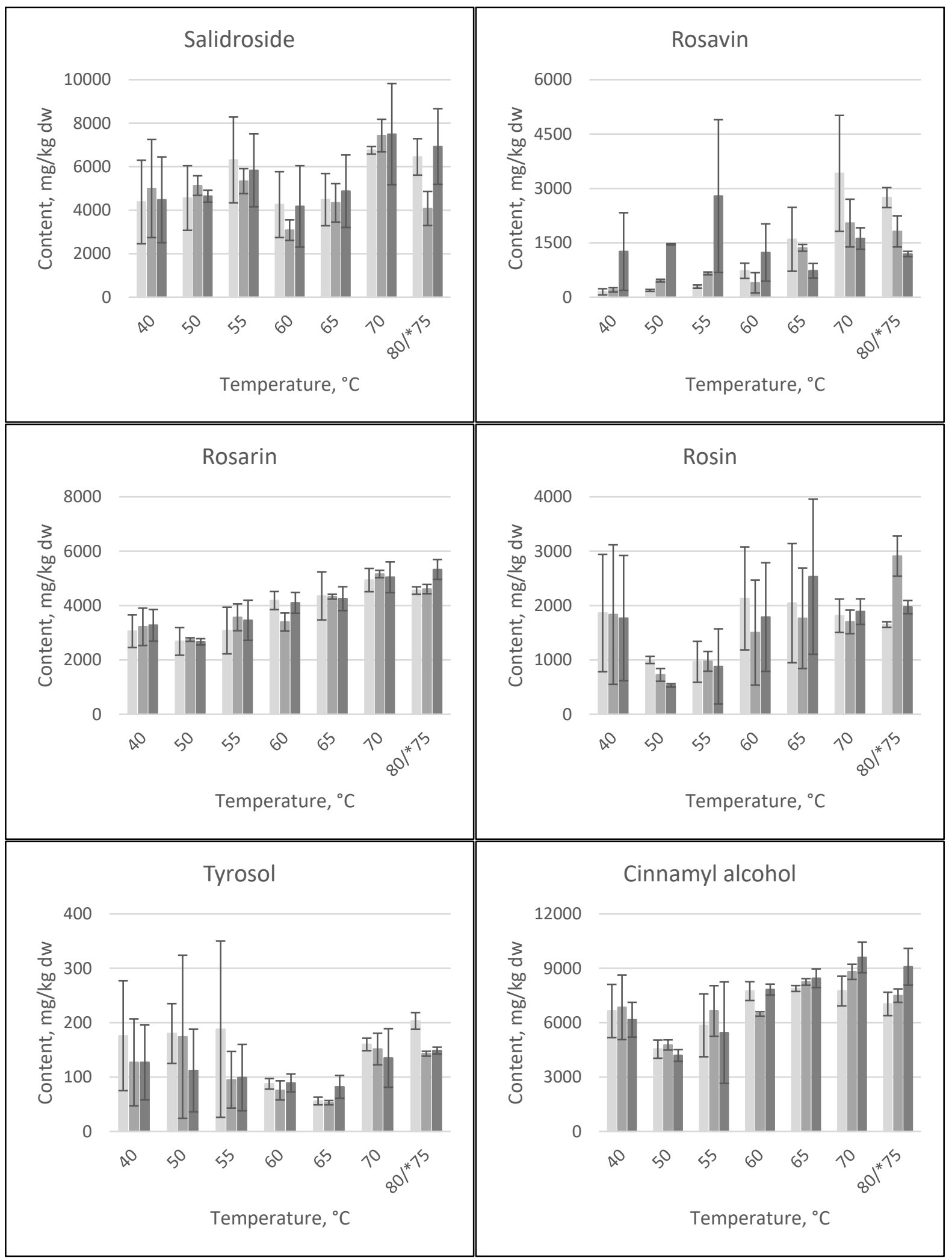

Fig. 7 Content of salidroside, rosavin, rosarin, rosin, tyrosol and cinnamyl alcohol in the rhizomes and roots of roseroot, where is the drying oven, the convective dryer and $\bullet$ the vacuum dryer.

*The convective dryer could not reach $80^{\circ} \mathrm{C}$, so the highest drying temperature was $75^{\circ} \mathrm{C}$. 
Peschel et al. (2016) [21] found that the content of rosavins in the rhizomes of roseroot slightly decreased at high drying temperature $\left(65^{\circ} \mathrm{C}\right)$, but the content of salidroside increased. The drying temperature $\left(45\right.$ and $65{ }^{\circ} \mathrm{C}$ ) did not seem to affect cinnamyl alcohol content. Thus, the results of Peschel et al. (2016) [21] are somewhat contrasted with this study. However, Peschel et al. (2016) [21] dried the rhizomes for five days at both 45 and $65^{\circ} \mathrm{C}$, which is an unnecessarily long heating period at $65^{\circ} \mathrm{C}$.

Thomsen et al. (2011) [27] found that the content of rosavins was significantly higher when the rhizomes of roseroot were dried at or below $50{ }^{\circ} \mathrm{C}$. They also noticed that if the rhizomes were dried at low drying temperatures, the content of rosavins decreased less during one-year storage. To salidroside content, the drying temperature did not appear to have an effect, but the cinnamyl alcohol content increased at high drying temperatures $\left(60-80^{\circ} \mathrm{C}\right)$, which is in line with this study.

Rodríguez et al. (2016) [28] noticed in the drying of maqui berries that high drying temperatures often caused less degradation of individual phenolic acids and flavonoids. They concluded that in some cases this could be due to conversion, as hydrolysable tannins can convert to ellagic acid and gallic acid. The conversion may also explain the increase in cinnamyl alcohol content at high drying temperatures, as cinnamyl alcohol is a precursor to rosarin, rosavin and rosin $[11,12]$. However, that does not explain the increase in rosarin content.

Thermal load, consisting of the combined effect of heat exposure time and temperature, may have undesirable effects on the content of active compounds [28]. In the drying of mulberry leaves, Katsube et al. (2009) [29] found that the antioxidant capacity and contents of individual polyphenols were higher when dried at 80 and $110^{\circ} \mathrm{C}$ instead of $70^{\circ} \mathrm{C}$. This may have been due to higher thermal load, as the drying time is longer at $70^{\circ} \mathrm{C}$. However, the same phenomenon was not observed when dried at 40 and $60^{\circ} \mathrm{C}$ instead of $70^{\circ} \mathrm{C}$. Consequently, the thermal load does not solely explain why higher rosarin content, cinnamyl alcohol content, TPC and AC were observed in this study at high drying temperatures.

\section{Conclusions}

Standard deviation of TPC and AC was lower in birch leaves than in nettle leaves and roseroot. This was probably due to homogenization, as birch leaves were easy to mix and divide into small drying batches. Standard deviation of roseroot was likely to be higher because the roots and rhizomes were dried in slices and their ratio was not determined. Nettle leaves had high moisture content in some samples, possibly affecting microbiological activity and quality, thus increasing the standard deviation. 
Drying temperature from 40 to $80^{\circ} \mathrm{C}$ did not significantly affect TPC or AC of birch leaves. For nettle leaves, slightly higher TPC and AC were typically obtained when dried between 65 and $70{ }^{\circ} \mathrm{C}$ and for roseroot when dried between 70 and $80^{\circ} \mathrm{C}$ depending on the dryer. The greatest differences in quality were observed between the dryers. The highest TPC and AC were clearly obtained with the vacuum dryer, except in the case of roseroot. With roseroot, the vacuum dryer barely provided higher TPC and $\mathrm{AC}$ at low temperatures and at $70^{\circ} \mathrm{C}$ and above, the convective dryer provided slightly higher results.

The content of rosarin and cinnamyl alcohol in the rhizomes and roots of roseroot increased as the drying temperature increased. The highest contents were obtained at $70{ }^{\circ} \mathrm{C}$. Due to high standard deviation, the effect of the drying temperature on the content of salidroside, rosavin, rosin and tyrosol could not be determined. The effect of the dryers on the content of salidroside, tyrosol, cinnamyl alcohol and rosavins was also left uncertain.

Total electricity consumption decreased when the plants were dried at high drying temperatures, as the drying time was shorter. The faster the plants are dried, the faster the dryer will also be released to dry the next batch, enabling more plants being dried in a given time. Higher drying temperatures also prevent the growth of micro-organisms and reduce their content in dried plants [30]. Consequently, several reasons advocate the use of higher drying temperatures.

Plants can contain several compounds of interest that are desired to preserve during drying. In this case, the preservation of the compounds should be examined separately. However, if the energy costs or investments on the dryer are high compared with the increase in compound contents, improving quality is not economically viable. Thus, balancing quality and costs requires compromises in drying temperature and dryer, as well as knowledge on their impact on quality. Drying at 60 to $70^{\circ} \mathrm{C}$ is a good temperature compromise, where TPC and AC were high, energy consumption remained moderate and the temperature may not yet be too high for heat sensitive compounds.

\section{References}

1. European Parliament. The EU's organic food market: facts and rules (infographic). European $\begin{array}{lllllllll}\text { Parliament. } & \text { [Online] } & 11 & 7 & 2019 . & \text { [Cited: } & 2 & 10 & 2020 .]\end{array}$ https://www.europarl.europa.eu/news/en/headlines/society/20180404ST000909/the-eu-s-organicfood-market-facts-and-rules-infographic.

2. von Koeller, Elfrun, et al. Pure Growth from Natural Products. Boston Consulting Group. [Online] 3012 2019. [Cited: 210 2020.] https://www.bcg.com/publications/2019/pure-growth-naturalproducts.

3. Recent Developments in Food Characterization and Adulteration Detection: Technique-Oriented Perspectives. Cordella, Christophe, et al. 2002, J. Agric. Food Chem., Vol. 50, pp. 1751-1764; https://doi.org/10.1021/jf011096z 
4. Effect of drying methods on chemical composition and antioxidant activity of underutilized stinging nettle leaves. Shonte, Tigist T., Duodu, K. G. and de Kock, Henriëtte L. 2020, Heliyon, Vol. 6, p. e03938; https://doi.org/10.1016/j.heliyon.2020.e03938

5. Effects of drying and grinding in production of fruit and vegetable powders: A review. Karam, Marie Céleste, et al. 2016, J. Food Eng., Vol. 188, pp. 32 - 49; https://doi.org/10.1016/j.jfoodeng.2016.05.001

6. Effect of drying methods on the quality characteristics of dill (Anethum graveolens) greens. Naidu, M. Madhava, et al. 2016, Food Chem., Vol. 192, pp. 849 - 856; https://doi.org/10.1016/j.foodchem.2015.07.076

7. A critical review of methods for characterisation of polyphenolic compounds in fruits and vegetables. Ignat, Ioana, Volf, Irina and Popa, Valentin I. 2011, Food Chem., Vol. 126, pp. 1821 - 1835; https://doi.org/10.1016/j.foodchem.2010.12.026

8. Plant polyphenols as dietary antioxidants in human health and disease. Pandey, Kanti Bhooshan and Rizvi, Syed Ibrahim. 2009, Oxid. Med. Cell. Longev., Vol. 2, pp. 270 - 278; https://doi.org/10.4161/oxim.2.5.9498

9. Assessment of Total Phenolic and Flavonoid Content, Antioxidant Properties, and Yield of Aeroponically and Conventionally Grown Leafy Vegetables and Fruit Crops: A Comparative Study. Chandra, Suman, et al. 2014, Evidence-Based Complementary and Alternative Medicine, Vol. 2014; https://doi.org/10.1155/2014/253875

10. Oxidative Stress and Neurodegenerative Diseases: A Review of Upstream and Downstream Antioxidant Therapeutic Options. Uttara, Bayani, et al. 2009, Curr. Neuropharmacol., Vol. 7, pp. 65 74; https://doi.org/10.2174/157015909787602823

11. Antioxidant and Antibacterial Activity of Roseroot (Rhodiola rosea L.) Dry Extracts. Kosakowska, Olga, et al. 2018, Molecules, Vol. 23, pp. 1767 - 1781; https://doi.org/10.3390/molecules23071767

12. Enhancing the production of cinnamyl glycosides in compact callus aggregate cultures of Rhodiola rosea by biotransformation of cinnamyl alcohol. György, Zsuzsanna, et al. 2004, Plant Sci., Vol. 166, pp. 229 - 236; https://doi.org/10.1016/j.plantsci.2003.09.011

13. Müller, Joachim and Heindl, Albert. Drying of Medicinal Plants. Medicinal and Aromatic Plants. s.l. : Springer, 2006, pp. 237 - 252.

14. Evaluation of energy consumption in different drying methods. Motevali, Ali, Minaei, Saeid and Khoshtagaza, Mohammad Hadi. 2011, Energy Conversion and Management, Vol. 52, pp. 1192 - 1199; https://doi.org/10.1016/j.enconman.2010.09.014

15. Microwave drying process scale-up. Radoiu, Marilena. 2020, Chemical Engineering and Processing - Process Intensification, Vol. 155, p. 108088; https://doi.org/10.1016/j.cep.2020.108088

16. Comparison of energy parameters in various dryers. Motevali, Ali, et al. 2014, Energy Convers. Manag., Vol. 87, pp. 711 - 725; https://doi.org/10.1016/j.enconman.2014.07.012

17. Characterisation of the Convective Hot-Air Drying and Vacuum Microwave Drying of Cassia alata: Antioxidant Activity, Essential Oil Volatile Composition and Quality Studies. Chua, Lisa Yen Wen, et al. 24, 2019, Molecules, p. 1625; https://doi.org/10.3390/molecules24081625 
18. Extraction of Polyphenolic Compounds from Eucalyptus globulus Bark: Process Optimization and Screening for Biological Activity. Mota, Inês, et al. 2012, Ind. Eng. Chem. Res., Vol. 51, pp. 6991-7000; https://doi.org/10.1021/ie300103z

19. A comprehensive review of CUPRAC methodology. Özyürek, Mustafa, et al. 2011, Anal. Methods, Vol. 3, pp. 2439 - 2453; https://doi.org/10.1039/c1ay05320e

20. Phytochemical variations of Rhodiola rosea L. wild-grown in Bulgaria. Marchev, Andrey S., et al. 2017, Phytochem. Lett., Vol. 20, pp. 386 - 390; https://doi.org/10.1016/j.phytol.2016.12.030

21. Age and harvest season affect the pheny/propenoid content in cultivated European Rhodiola rosea L. Peschel, Wieland, et al. 2016, Ind. Crops Prod., Vol. 83, pp. 787-802; https://doi.org/10.1016/j.indcrop.2015.10.037

22. Effects of different drying temperatures on the content of phenolic compounds and carotenoids in quinoa seeds (Chenopodium quinoa) from Finland. Multari, Salvatore, et al. 72, 2018, J. Food Compos. Anal., pp. 75-82; https://doi.org/10.1016/j.jfca.2018.06.008

23. Optimization Of An Air-Drying Process To Obtain A Dehydrated Naranjita (Citrus Mitis B.) Pomace Product With High Bioactive Compounds And Antioxidant Capacity. Delgado-Nieblas, C.I., et al. 00, 2015, J. Food Process Eng., pp. 00-00; https://doi.org/10.1111/jfpe.12338

24. Analysis of Total Phenols and Other Oxidation Substrates and Antioxidants by Means of FolinCiocalteu Reagent. Singleton, Vernon L., Orthofer, Rudolf and Lamuela-Raventós, Rosa M. 299, 1999, Meth. Enzymol., pp. 152 - 178; https://doi.org/10.1016/S0076-6879(99)99017-1

25. Effect of Sample Preparation Method on Birch (Betula pendula Roth) Leaf Phenolics. Keinänen, Markku and Julkunen-Tiitto, Riitta. 44, 1996, J. Agric. Food Chem., pp. 2724 - 2727; https://doi.org/10.1021/jf960168x

26. Effect of provenance, plant part and processing on extract profiles from cultivated European Rhodiola rosea L. for medicinal use. Peschel, Wieland, et al. 86, 2013, Phytochemistry, pp. 92 - 102; https://doi.org/10.1016/j.phytochem.2012.10.005

27. Harvest Time And Drying Temperature Effect On Secundary Metabolites In Rhodiola Rosea. Thomsen, M. G., et al. 955, 2011, International Symposium on Medicinal, Aromatic and Nutraceutical Plants from Mountainous Areas (MAP-Mountain 2011), pp. 243-252; https://doi.org/10.17660/ActaHortic.2012.955.35

28. Changes in bioactive components and antioxidant capacity of maqui, Aristotelia chilensis [Mol] Stuntz, berries during drying. Rodríguez, Katia, et al. 65, 2016, LWT, pp. 537 - 542; https://doi.org/10.1016/j.lwt.2015.08.050

29. Effect of air-drying temperature on antioxidant capacity and stability of polyphenolic compounds in mulberry (Morus alba L.) leaves. Katsube, Takuya, et al. 113, 2009, Food Chem., pp. 964 - 969; https://doi.org/10.1016/j.foodchem.2008.08.041

30. de Freitas Araújo, Marcelo Gonzaga and Bauab, Taís Maria. Microbial Quality of Medicinal Plant Materials. Latest Research into Quality Control. s.I.: IntechOpen, 2012; https://doi.org/10.5772/51072 
Table 1. Drying time of the plants and electricity consumption of dryers.

\begin{tabular}{|c|c|c|c|c|}
\hline \multicolumn{5}{|c|}{ Nettle leaves } \\
\hline Dryer & Parameter & $40^{\circ} \mathrm{C}$ & $60^{\circ} \mathrm{C}$ & $80 / * 75^{\circ} \mathrm{C}$ \\
\hline \multirow{3}{*}{ Convective dryer } & Drying time $(\mathrm{h})$ & 1.93 & 0.85 & 0.50 \\
\hline & Electricity consumption (kWh) & 0.23 & 0.53 & 0.98 \\
\hline & Total electricity consumption (kWh) & 0.44 & 0.45 & 0.49 \\
\hline \multirow{3}{*}{ Drying oven } & Drying time $(\mathrm{h})$ & 4.67 & 1.75 & 1.00 \\
\hline & Electricity consumption (kWh) & 0.02 & 0.04 & 0.08 \\
\hline & Total electricity consumption (kWh) & 0.07 & 0.07 & 0.08 \\
\hline \multirow{3}{*}{ Vacuum dryer } & Drying time $(\mathrm{h})$ & 2.50 & 1.33 & 0.50 \\
\hline & Electricity consumption (kWh) & 0.33 & 0.33 & 0.37 \\
\hline & Total electricity consumption (kWh) & 0.81 & 0.44 & 0.19 \\
\hline \multicolumn{5}{|c|}{ Birch leaves } \\
\hline Dryer & Parameter & $40^{\circ} \mathrm{C}$ & $60^{\circ} \mathrm{C}$ & $80 / * 75^{\circ} \mathrm{C}$ \\
\hline \multirow{3}{*}{ Convective dryer } & Drying time $(\mathrm{h})$ & 8.33 & 1.42 & 1.00 \\
\hline & Electricity consumption (kWh) & 0.23 & 0.53 & 0.98 \\
\hline & Total electricity consumption (kWh) & 1.88 & 0.74 & 0.98 \\
\hline \multirow{3}{*}{ Drying oven } & Drying time $(\mathrm{h})$ & 12.00 & 3.67 & 1.42 \\
\hline & Electricity consumption (kWh) & 0.02 & 0.04 & 0.08 \\
\hline & Total electricity consumption (kWh) & 0.18 & 0.15 & 0.11 \\
\hline \multirow{3}{*}{ Vacuum dryer } & Drying time $(\mathrm{h})$ & 6.83 & 2.58 & 1.33 \\
\hline & Electricity consumption (kWh) & 0.33 & 0.33 & 0.37 \\
\hline & Total electricity consumption (kWh) & 2.22 & 0.85 & 0.49 \\
\hline \multicolumn{5}{|c|}{ Roseroot } \\
\hline Dryer & Parameter & $40^{\circ} \mathrm{C}$ & $60^{\circ} \mathrm{C}$ & $80 / * 75^{\circ} \mathrm{C}$ \\
\hline \multirow{3}{*}{ Convective dryer } & Drying time $(\mathrm{h})$ & 22.75 & 2.75 & 2.53 \\
\hline & Electricity consumption (kWh) & 0.23 & 0.53 & 0.98 \\
\hline & Total electricity consumption (kWh) & 5.12 & 1.44 & 2.48 \\
\hline \multirow{3}{*}{ Drying oven } & Drying time $(\mathrm{h})$ & 22.75 & 5.08 & 1.87 \\
\hline & Electricity consumption (kWh) & 0.02 & 0.04 & 0.08 \\
\hline & Total electricity consumption (kWh) & 0.34 & 0.20 & 0.14 \\
\hline \multirow{3}{*}{ Vacuum dryer } & Drying time $(\mathrm{h})$ & 22.75 & 5.08 & 3.08 \\
\hline & Electricity consumption (kWh) & 0.33 & 0.33 & 0.37 \\
\hline & Total electricity consumption (kWh) & 7.39 & 1.68 & 1.14 \\
\hline
\end{tabular}

\footnotetext{
*The convective dryer could not reach $80^{\circ} \mathrm{C}$, so the highest drying temperature was $75^{\circ} \mathrm{C}$.
} 
Table 1. Average moisture content of the dried plants from each dryer at each temperature.

\begin{tabular}{|c|c|c|c|c|c|c|c|c|c|}
\hline \multirow{2}{*}{$\begin{array}{c}\text { Temp. } \\
\left({ }^{\circ} \mathrm{C}\right)\end{array}$} & \multicolumn{2}{|c|}{$\begin{array}{c}\text { Moisture content of } \\
\text { nettle leaves (m-\%) }\end{array}$} & \multicolumn{2}{c|}{$\begin{array}{c}\text { Moisture content of } \\
\text { birch leaves (m-\%) }\end{array}$} & \multicolumn{3}{c|}{$\begin{array}{c}\text { Moisture content of } \\
\text { roseroot (m-\%) }\end{array}$} \\
\cline { 2 - 11 } & $\begin{array}{c}\text { Drying } \\
\text { oven }\end{array}$ & $\begin{array}{c}\text { Convec. } \\
\text { dryer }\end{array}$ & $\begin{array}{c}\text { Vacuum } \\
\text { dryer }\end{array}$ & $\begin{array}{c}\text { Drying } \\
\text { oven }\end{array}$ & $\begin{array}{c}\text { Convec. } \\
\text { dryer }\end{array}$ & $\begin{array}{c}\text { Vacuum } \\
\text { dryer }\end{array}$ & $\begin{array}{c}\text { Drying } \\
\text { oven }\end{array}$ & $\begin{array}{c}\text { Convec. } \\
\text { dryer }\end{array}$ & $\begin{array}{c}\text { Vacuum } \\
\text { dryer }\end{array}$ \\
\hline \multirow{2}{*}{$\mathbf{4 0}$} & $21.34 \pm$ & $23.86 \pm$ & $20.34 \pm$ & $5.75 \pm$ & $7.74 \pm$ & $5.18 \pm$ & $7.80 \pm$ & $5.85 \pm$ & $4.70 \pm$ \\
& 0.34 & 3.47 & 1.94 & 0.02 & 2.07 & 1.55 & 0.10 & 0.35 & 0.70 \\
\hline \multirow{2}{*}{$\mathbf{5 0}$} & $17.62 \pm$ & $13.06 \pm$ & $18.01 \pm$ & $8.28 \pm$ & $9.55 \pm$ & $6.30 \pm$ & $9.55 \pm$ & $10.20 \pm$ & $7.30 \pm$ \\
& 3.63 & 0.66 & 2.11 & 0.37 & 0.64 & 1.05 & 2.25 & 2.10 & 0.20 \\
\hline \multirow{2}{*}{$\mathbf{5 5}$} & $11.34 \pm$ & $11.61 \pm$ & $14.77 \pm$ & $7.02 \pm$ & $6.47 \pm$ & $4.52 \pm$ & $11.95 \pm$ & $9.00 \pm$ & $5.25 \pm$ \\
& 1.28 & 5.01 & 1.98 & 1.27 & 1.43 & 0.66 & 1.65 & 0.00 & 0.25 \\
\hline \multirow{2}{*}{$\mathbf{6 0}$} & $10.66 \pm$ & $8.97 \pm$ & $10.95 \pm$ & $7.15 \pm$ & $8.73 \pm$ & $7.14 \pm$ & $11.85 \pm$ & $10.46 \pm$ & $7.86 \pm$ \\
& 0.85 & 1.58 & 1.27 & 0.39 & 0.05 & 0.51 & 0.40 & 1.50 & 1.98 \\
\hline \multirow{2}{*}{$\mathbf{6 5}$} & $14.45 \pm$ & $11.17 \pm$ & $9.09 \pm$ & $8.16 \pm$ & $5.93 \pm$ & $5.75 \pm$ & $12.42 \pm$ & $7.86 \pm$ & $9.23 \pm$ \\
& 3.22 & 4.29 & 3.72 & 1.84 & 1.14 & 1.10 & 2.29 & 3.25 & 7.18 \\
\hline \multirow{2}{*}{$\mathbf{7 0}$} & $5.73 \pm$ & $8.43 \pm$ & $15.73 \pm$ & $8.41 \pm$ & $4.43 \pm$ & $4.18 \pm$ & $13.76 \pm$ & $7.10 \pm$ & $5.05 \pm$ \\
& 1.21 & 3.83 & 0.41 & 2.75 & 0.25 & 0.44 & 1.26 & 1.50 & 2.17 \\
\hline \multirow{2}{*}{$\mathbf{8 0}{ }^{* 75}$} & $6.20 \pm$ & 10.58 & $10.82 \pm$ & $5.66 \pm$ & $3.03 \pm$ & $4.86 \pm$ & $9.35 \pm$ & $8.25 \pm$ & $5.30 \pm$ \\
& 0.28 & \pm 6.01 & 7.16 & 1.43 & 0.52 & 1.62 & 4.65 & 0.75 & 2.80 \\
\hline
\end{tabular}

*The convective (convec.) dryer could not reach $80^{\circ} \mathrm{C}$, so the highest drying temperature was $75^{\circ} \mathrm{C}$. 
Table 1. Total polyphenol content (TPC) and antioxidant capacity (AC) of nettle leaves at each drying temperature.

\begin{tabular}{|c|c|c|c|c|c|c|}
\hline \multirow{2}{*}{$\begin{array}{c}\text { Temp. } \\
\left({ }^{\circ} \mathbf{C}\right)\end{array}$} & \multicolumn{2}{|c|}{ Drying oven } & \multicolumn{2}{c|}{ Convective dryer } & \multicolumn{2}{c|}{ Vacuum dryer } \\
\cline { 2 - 7 } & $\begin{array}{c}\text { TPC } \\
\mathbf{m g} / \mathbf{g})\end{array}$ & $\begin{array}{c}\text { AC } \\
(\mathbf{m m o l} / \mathbf{g})\end{array}$ & $\begin{array}{c}\text { TPC } \\
(\mathbf{m g} / \mathbf{g})\end{array}$ & $\begin{array}{c}\text { AC } \\
(\mathbf{m m o l} / \mathbf{g})\end{array}$ & $\begin{array}{c}\text { TPC } \\
(\mathbf{m g} / \mathbf{g})\end{array}$ & $\begin{array}{c}\text { AC } \\
(\mathbf{m m o l} / \mathbf{g})\end{array}$ \\
\hline \multirow{2}{*}{$\mathbf{4 0}$} & 4.43 & 0.038 & 4.87 & 0.040 & 12.29 & 0.156 \\
& \pm 0.12 & \pm 0.003 & \pm 0.69 & \pm 0.007 & \pm 1.36 & \pm 0.016 \\
\hline \multirow{2}{*}{$\mathbf{5 0}$} & 6.13 & 0.051 & 6.28 & 0.038 & 13.98 & 0.165 \\
& \pm 0.42 & \pm 0.005 & \pm 0.83 & \pm 0.012 & \pm 1.91 & \pm 0.016 \\
\hline \multirow{2}{*}{$\mathbf{5 5}$} & 4.26 & 0.038 & 5.77 & 0.046 & 13.86 & 0.163 \\
& \pm 0.09 & \pm 0.001 & \pm 0.43 & \pm 0.004 & \pm 0.22 & \pm 0.009 \\
\hline \multirow{2}{*}{$\mathbf{6 0}$} & 4.66 & 0.036 & 6.45 & 0.052 & 12.83 & 0.141 \\
& \pm 0.35 & \pm 0.003 & \pm 0.68 & \pm 0.005 & \pm 1.37 & \pm 0.021 \\
\hline \multirow{2}{*}{$\mathbf{6 5}$} & 4.60 & 0.035 & 6.51 & 0.055 & 17.84 & 0.195 \\
& \pm 0.28 & \pm 0.003 & \pm 1.36 & \pm 0.009 & \pm 2.75 & \pm 0.044 \\
\hline \multirow{2}{*}{$\mathbf{7 0}$} & 4.69 & 0.034 & 6.04 & 0.050 & 13.80 & 0.158 \\
& \pm 0.67 & \pm 0.005 & \pm 1.69 & \pm 0.012 & \pm 0.94 & \pm 0.020 \\
\hline \multirow{2}{*}{$\mathbf{8 0} / \mathbf{7 5}$} & 4.19 & 0.031 & 6.67 & 0.056 & 9.91 & 0.129 \\
& \pm 0.27 & \pm 0.003 & \pm 0.22 & \pm 0.001 & \pm 1.39 & \pm 0.020 \\
\hline
\end{tabular}

${ }^{*}$ The convective dryer could not reach $80^{\circ} \mathrm{C}$, so the highest drying temperature was $75^{\circ} \mathrm{C}$.

Table 2. Total polyphenol content (TPC) and antioxidant capacity (AC) of birch leaves at each drying temperature.

\begin{tabular}{|c|c|c|c|c|c|c|}
\hline \multirow{2}{*}{$\begin{array}{c}\text { Temp. } \\
\left({ }^{\circ} \mathrm{C}\right)\end{array}$} & \multicolumn{2}{|c|}{ Drying oven } & \multicolumn{2}{c|}{ Convective dryer } & \multicolumn{2}{c|}{ Vacuum dryer } \\
\cline { 2 - 7 } & $\begin{array}{c}\text { TPC } \\
(\mathbf{m g} / \mathbf{g})\end{array}$ & $\begin{array}{c}\text { AC } \\
(\mathbf{m m o l} / \mathbf{g})\end{array}$ & $\begin{array}{c}\text { TPC } \\
(\mathbf{m g} / \mathbf{g})\end{array}$ & $\begin{array}{c}\text { AC } \\
(\mathbf{m m o l} / \mathbf{g})\end{array}$ & $\begin{array}{c}\text { TPC } \\
(\mathbf{m g} / \mathbf{g})\end{array}$ & $\begin{array}{c}\text { AC } \\
(\mathbf{m m o l} / \mathbf{g})\end{array}$ \\
\hline \multirow{2}{*}{$\mathbf{4 0}$} & 42.40 & 0.420 & 45.33 & 0.458 & 65.31 & 0.687 \\
& \pm 2.44 & \pm 0.034 & \pm 0.49 & \pm 0.004 & \pm 1.37 & \pm 0.023 \\
\hline \multirow{2}{*}{$\mathbf{5 0}$} & 44.09 & 0.460 & 48.14 & 0.498 & 57.62 & 0.611 \\
& \pm 2.51 & \pm 0.038 & \pm 1.51 & \pm 0.017 & \pm 3.85 & \pm 0.062 \\
\hline \multirow{2}{*}{$\mathbf{5 5}$} & 44.24 & 0.437 & 45.59 & 0.472 & 64.74 & 0.685 \\
& \pm 1.21 & \pm 0.017 & \pm 4.62 & \pm 0.052 & \pm 4.23 & \pm 0.051 \\
\hline \multirow{2}{*}{$\mathbf{6 0}$} & 43.70 & 0.440 & 46.10 & 0.485 & 58.97 & 0.608 \\
& \pm 1.38 & \pm 0.021 & \pm 2.33 & \pm 0.023 & \pm 2.92 & \pm 0.039 \\
\hline \multirow{2}{*}{$\mathbf{6 5}$} & 44.01 & 0.438 & 51.51 & 0.521 & 65.14 & 0.689 \\
& \pm 1.33 & \pm 0.014 & \pm 0.99 & \pm 0.033 & \pm 1.02 & \pm 0.010 \\
\hline \multirow{2}{*}{$\mathbf{7 0}$} & 41.78 & 0.497 & 52.63 & 0.539 & 58.45 & 0.665 \\
& \pm 0.82 & \pm 0.026 & \pm 1.54 & \pm 0.022 & \pm 2.48 & \pm 0.022 \\
\hline \multirow{2}{*}{$\mathbf{8 0 / * 7 5}$} & 46.22 & 0.535 & 50.27 & 0.575 & 59.29 & 0.686 \\
& \pm 0.82 & \pm 0.018 & \pm 0.65 & \pm 0.024 & \pm 1.11 & \pm 0.028 \\
\hline
\end{tabular}

*The convective dryer could not reach $80^{\circ} \mathrm{C}$, so the highest drying temperature was $75^{\circ} \mathrm{C}$. 
Table 3. Total polyphenol content (TPC) and antioxidant capacity (AC) of roots and rhizomes of roseroot at each drying temperature.

\begin{tabular}{|c|c|c|c|c|c|c|}
\hline \multirow{2}{*}{$\begin{array}{c}\text { Temp. } \\
\left({ }^{\circ} \mathbf{C}\right)\end{array}$} & \multicolumn{2}{|c|}{ Drying oven } & \multicolumn{2}{c|}{ Convective dryer } & \multicolumn{2}{c|}{ Vacuum dryer } \\
& $\mathbf{\text { TPg/g) }}$ & $\begin{array}{c}\text { AC } \\
(\mathbf{m m o l} / \mathbf{g})\end{array}$ & $\begin{array}{c}\text { TPC } \\
(\mathbf{m g} / \mathbf{g})\end{array}$ & $\begin{array}{c}\text { AC } \\
(\mathbf{m m o l} / \mathbf{g})\end{array}$ & $\begin{array}{c}\text { TPC } \\
(\mathbf{m g} / \mathbf{g})\end{array}$ & $\begin{array}{c}\text { AC } \\
(\mathbf{m m o l} / \mathbf{g})\end{array}$ \\
\hline \multirow{2}{*}{$\mathbf{4 0}$} & 110.52 & 1.399 & 109.08 & 1.385 & 120.75 & 1.558 \\
& \pm 1.24 & \pm 0.012 & \pm 4.87 & \pm 0.046 & \pm 5.97 & \pm 0.063 \\
\hline \multirow{2}{*}{$\mathbf{5 0}$} & 120.60 & 1.610 & 124.50 & 1.648 & 127.34 & 1.700 \\
& \pm 13.35 & \pm 0.122 & \pm 2.44 & \pm 0.057 & \pm 5.40 & \pm 0.160 \\
\hline \multirow{2}{*}{$\mathbf{5 5}$} & 92.24 & 1.287 & 110.29 & 1.572 & 118.71 & 1.676 \\
& \pm 4.93 & \pm 0.028 & \pm 23.67 & \pm 0.323 & \pm 14.83 & \pm 0.190 \\
\hline \multirow{2}{*}{$\mathbf{6 0}$} & 101.41 & 1.483 & 90.33 & 1.320 & 105.19 & 1.527 \\
& \pm 9.99 & \pm 0.162 & \pm 8.26 & \pm 0.132 & \pm 2.16 & \pm 0.049 \\
\hline \multirow{2}{*}{$\mathbf{6 5}$} & 111.27 & 1.293 & 108.91 & 1.242 & 120.73 & 1.430 \\
& \pm 10.65 & \pm 0.196 & \pm 7.89 & \pm 0.251 & \pm 4.91 & \pm 0.268 \\
\hline \multirow{2}{*}{$\mathbf{7 0}$} & 164.37 & 1.542 & 180.15 & 1.657 & 161.21 & 1.446 \\
& \pm 30.65 & \pm 0.270 & \pm 5.25 & \pm 0.049 & \pm 23.51 & \pm 0.214 \\
\hline \multirow{2}{*}{$\mathbf{8 0 / * 7 5}$} & 180.78 & 1.734 & 209.39 & 1.970 & 195.81 & 1.863 \\
& \pm 10.48 & \pm 0.117 & \pm 9.04 & \pm 0.112 & \pm 6.38 & \pm 0.072 \\
\hline
\end{tabular}

*The convective dryer could not reach $80^{\circ} \mathrm{C}$, so the highest drying temperature was $75^{\circ} \mathrm{C}$.

Table 4. Content of active compounds of roots and rhizomes of roseroot at each drying temperature.

\begin{tabular}{|c|c|c|c|c|c|c|}
\hline \multicolumn{7}{|c|}{ Drying oven } \\
\hline $\begin{array}{c}\text { Temp. } \\
\left({ }^{\circ} \mathrm{C}\right)\end{array}$ & $\begin{array}{l}\text { Salidroside } \\
\text { (mg/g) }\end{array}$ & $\begin{array}{l}\text { Rosarin } \\
(\mathrm{mg} / \mathrm{g})\end{array}$ & $\begin{array}{l}\text { Rosavin } \\
(\mathrm{mg} / \mathrm{g})\end{array}$ & $\begin{array}{l}\text { Rosin } \\
\text { (mg/g) }\end{array}$ & $\begin{array}{l}\text { Tyrosol } \\
(\mathrm{mg} / \mathrm{g})\end{array}$ & $\begin{array}{c}\text { Cinnamyl alc. } \\
(\mathrm{mg} / \mathrm{g})\end{array}$ \\
\hline 40 & $4378 \pm 1922$ & $3057 \pm 602$ & $149 \pm 85$ & $1862 \pm 1079$ & $176 \pm 101$ & $6644 \pm 1469$ \\
\hline 50 & $4561 \pm 1487$ & $2684 \pm 510$ & $189 \pm 26$ & $1001 \pm 66$ & $180 \pm 55$ & $4541 \pm 503$ \\
\hline 55 & $6310 \pm 1974$ & $3081 \pm 858$ & $294 \pm 44$ & $966 \pm 377$ & $188 \pm 162$ & $5852 \pm 1732$ \\
\hline 60 & $4259 \pm 1513$ & $4185 \pm 333$ & $729 \pm 209$ & $2131 \pm 946$ & $88 \pm 10$ & $7741 \pm 518$ \\
\hline 65 & $4487 \pm 1201$ & $4353 \pm 881$ & $1598 \pm 881$ & $2044 \pm 1096$ & $56 \pm 7$ & $7885 \pm 162$ \\
\hline 70 & $6757 \pm 176$ & $4937 \pm 429$ & $3417 \pm 1598$ & $1813 \pm 307$ & $160 \pm 11$ & $7744 \pm 820$ \\
\hline 80 & $6452 \pm 837$ & $4554 \pm 136$ & $2749 \pm 276$ & $1650 \pm 50$ & $203 \pm 15$ & $7032 \pm 645$ \\
\hline \multicolumn{7}{|c|}{ Convective dryer } \\
\hline 40 & $4996 \pm 2254$ & $3220 \pm 688$ & $201 \pm 59$ & $1834 \pm 1283$ & $127 \pm 80$ & $6848 \pm 1782$ \\
\hline 50 & $5132 \pm 451$ & $2749 \pm 65$ & $458 \pm 38$ & $725 \pm 117$ & $174 \pm 150$ & $4772 \pm 282$ \\
\hline 55 & $5338 \pm 574$ & $3566 \pm 492$ & $658 \pm 38$ & $975 \pm 182$ & $95 \pm 52$ & $6644 \pm 1399$ \\
\hline 60 & $3085 \pm 469$ & $3394 \pm 333$ & $398 \pm 278$ & $1503 \pm 965$ & $76 \pm 18$ & $6481 \pm 123$ \\
\hline 65 & $4339 \pm 883$ & $4327 \pm 92$ & $1362 \pm 94$ & $1766 \pm 924$ & $53 \pm 4$ & $8246 \pm 181$ \\
\hline 70 & $7432 \pm 749$ & $5160 \pm 133$ & $2045 \pm 659$ & $1700 \pm 217$ & $151 \pm 29$ & $8805 \pm 419$ \\
\hline 75 & $4079 \pm 785$ & $4605 \pm 172$ & $1816 \pm 429$ & $2910 \pm 369$ & $143 \pm 5$ & $7493 \pm 371$ \\
\hline \multicolumn{7}{|c|}{ Vacuum dryer } \\
\hline 40 & $4478 \pm 1972$ & $3276 \pm 582$ & $1260 \pm 1070$ & $1769 \pm 1151$ & $127 \pm 69$ & $6164 \pm 959$ \\
\hline 50 & $4646 \pm 275$ & $2666 \pm 116$ & $1460 \pm 17$ & $532 \pm 31$ & $112 \pm 76$ & $4195 \pm 325$ \\
\hline 55 & $5836 \pm 1676$ & $3460 \pm 738$ & $2789 \pm 2107$ & $881 \pm 691$ & $99 \pm 61$ & $5450 \pm 2798$ \\
\hline 60 & $4177 \pm 1872$ & $4101 \pm 383$ & $1235 \pm 789$ & $1789 \pm 998$ & $89 \pm 16$ & $7828 \pm 299$ \\
\hline 65 & $4874 \pm 1668$ & $4255 \pm 439$ & $731 \pm 200$ & $2531 \pm 1427$ & $82 \pm 21$ & $8451 \pm 514$ \\
\hline 70 & $7494 \pm 2326$ & $5043 \pm 564$ & $1620 \pm 295$ & $1889 \pm 235$ & $135 \pm 54$ & $9600 \pm 848$ \\
\hline 80 & $6930 \pm 1738$ & $5327 \pm 367$ & $1193 \pm 71$ & $1972 \pm 121$ & $149 \pm 6$ & $9082 \pm 1017$ \\
\hline
\end{tabular}




\section{Supplementary Files}

This is a list of supplementary files associated with this preprint. Click to download.

- Supplementarymaterial.pdf 